\title{
Interaction Between a Teacher and the Non-speaking as well as Speaking Children in the Classroom
}

\author{
Elsa Popich and Erna Alant
}

Centre for Augmentative and Alternative Communication, Department of Communication Pathology, University of Pretoria

\begin{abstract}
This study examined the verbal interactions which occurred between a teacher and two groups of children (children who were non-speaking as well as children who were speaking). Descriptive data, generated by analysing ten lessons, suggested that the teacher's interaction with the children who were non-speaking differed, in terms of quantity and quality. She directed approximately $10 \%$ less interaction at each of the three non-speaking children, when compared with the number of interactions that she directed at each of the five speaking children. However, she did not spend an equal amount of time interacting with each of the non-speaking children. Her interaction with the non-speaking children was dominated by questions, attention directing and requesting. Verbalization types, such as answering and imitating did not occur at all in the teacher's interaction with the non-speaking children. This implies that the non-speaking children's learning experiences in the classroom differed from the speaking children's learning experiences. Possible reasons for these discrepancies were proposed, namely that the teacher's attitudes, skill and knowledge played a role, but the non-speaking children's lack of access to communication was also considered to be a factor in determining the amount and type of interaction.
\end{abstract}

\section{OPSOMMING}

Hierdie studie het die verbale interaksie tussen 'n onderwyseres en twee groepe kinders(kinders wat nie-sprekend is sowel as kinders wat sprekend is\} bestudeer. Beskrywende data wat gegenereer is deur die analise van tien lesse, suggereer dat die onderwyseres se interaksie met die nie-sprekende kinders verskil het in terme van hoeveelheid en kwaliteit. Sy het ongeveer $10 \%$ minder interaksie aan elkeen van die drie nie-sprekende kinders gerig in vergelyking met die aantal interaksies wat sy aan elkeen van die vyf sprekende kinders gerig het. Sy het egter nie ewe veel gepraat met elkeen van die nie-sprekende kinders nie. Haar interaksie met die nie-sprekende kinders het oorwegend uit vrae, aandag rig en versoeke bestaan. Verbalisasies, soos antwoorde en nabootsing het nie voorgekom in die onderwyseres se interaksie met die nie-sprekende kinders nie. Dit impliseer dat die nie-sprekende kinders se leerervarings in die klas verskil van die sprekende kinders se leerervarings. Moontlike redes vir hierdie verskille was voorgestel, naamlik dat die onderwyseres se houdings, vermoë en kennis 'n rol speel, maar dăt die nie-sprekende kinders se beperkte toegang tot kommunikasie ook 'n deurslaggewende rol in die bepaling van die hoeveelheid en tipe interaksie, gespeel het.

KEYWORDS: classroom interaction; non-speaking; verbalization types.

When a child has difficulty in actively participating in class, the problems the child experiences could be due to either the fact that the child does not have access to communication or that the child is not given the opportunity to interact (Beukelman \& Mirenda, 1992). Although one can separate factors relating to access and opportunities for communication, these aspects are interrelated. The mere provision of a means to gain access to interaction is not sufficient to increase the participation of the nonspeaking child. Training of potential communication partners in the provision of interaction opportunities forms an important additional component of the intervention process (Calculator \& Luchko, 1983).

Limited access to communication is related to the mode of communication the child uses (Beukelman \& Mirenda, 1992). For the non-speaking child, who cannot meet all of his communication needs through speech, another mode should be considered in order to increase access to communication, for example the use of an alternative and augmentative communication (AAC) system. Providing a suitable system to facilitate interaction means that the system should aim not only to increase the intelligibility of the communication attempts but also the rate of message transmission and the child's general access to a portable communication system (Beukelman \& Yorkston, 1982). Providing the correct AAC system is thus important to ensure participation in the classroom in meaningful interactions. However, only providing the child with access to communication does not ensure an increase in learning (Beukelman, 1991). Due to the fact that AAC users in the classroom primarily occupy a respondent role it is equally important for learning that the child not only 
be given access to communication but also be provided with the opportunity to interact (Dalton \& Bedrosian, 1989). Opportunity barriers are, therefore, an important aspect to be considered in the description of classroom interaction and teachers will have to assume at least some of the responsibility when AAC users fail to interact (Mirenda \& Donnellan, 1986).

The extent to which a child is included in classroom interaction is affected by the teacher creating opportunities for the child to communicate (Beukelman \& Mirenda, 1992). The less the child's speaking abilities, the more difficult for the teacher to ensure the child's participation in interaction. Factors such as the teacher's attitude towards the non-speaking child, the teacher's knowledge of the importance of interaction for the increasing intelligibility of the non-speaking child and the teacher's skill in including the non-speaking child in interaction; will determine the success with which the non-speaking child is included in classroom interaction.

Teaching strategies that do not actively demand the participation of the AAC user will result in increasing passivity in the non-speaking child (Bottorf \& dePape, 1982). Research has indicated that AAC users in the classroom situation seldom initiate interaction (Basil, 1992) and that this lack of social interaction often results in a decrease in language competence and in fewer learning opportunities being available to the non-speaking child (Grayshon, 1977).

In spite of evidence that a high level of responsiveness on the part of the teacher will have a positive influence on the child's conversational abilities (Mirenda \& Donnellan, 1986), it was found that more than fifty percent of the initiations made by mentally handicapped pupils to teachers were not responded to (Beveridge \& Hurrel, 1980). Factors contributing to the frequency and quality of teachers responses to the non-speaking children are three-fold. Firstly, the teacher's lack of responsiveness can be attributed to the teacher's expectations of the individual child (low or high achiever) with more opportunities for interaction being offered to the higher-achieving individual (Iight \& McNaughton, 1993). Secondly, the teacher may limit the number of interactions with the child due to the fact that she cannot predict the child's capabilities in performing certain tasks in interaction (Light \& McNaughton, 1993). Therefore, the non-speaking child may under- achieve, which could lead to the teacher giving him even fewer opportunities due to her lowered expectations of him. Thirdly, the teacher's responses to child-initiated interaction are related to the personality of the child, for example, the presence of disruptive behaviour could lead to the child being given fewer opportunities to interact (Beveridge, Ramsden \& Leudar, 1989). Although aggression is often seen in non-speaking children due to the frustration of not being understood the abscence of aggression is crucial so as not to result in exclusion from communication (Baumgart, Johnson \& Helmsetter, 1990). It would seem that a vicious circle could develop, with teachers giving fewer opportunities to non-speaking children, and the children interacting less as a consequence of the teacher's lack of responsiveness to them.

Not only does the teacher influence the child's participation, but there is evidence that the quantity and quality of an adult's verbal behaviour is related to the verbal output of the child with whom they are interacting (Mirenda \& Donnellan, 1986). Interaction can be seen as a pattern of mutual influence and adjustment (MalamahThomas, 1988). Consequently, the more verbal the child is, the more frcquent the interaction with the teacher. In an evaluation of the frequency of the interaction between a teacher and the speaking, as well as non-speaking members of the class, one could therefore expect the teacher to interact more with the children who have a higher verbal output. As mentioned previously, the amount of opportunities the teacher gives to the non-speaking children, will have an important influence on their level of participation and learning. Various studies have indicated that not only the quantity, but the quality of interactions between the non-speaking child and the teacher is different from the interactions between the speaking child and the teacher (Cicognani \& Zani, 1992). The degree of impairment of verbal abilities in a child affects the adult language used in communication. Teachers' interactions with children with disabilities mainly consisted of instructions, statements and questions while interaction types such as affirming and praise seldom occurred (Harris, 1982; Klein $\&$ Harris, 1986). Furthermore the questions that were directed at children with disabilities were mostly questions that only required a yes/no response (Lossing, Yorkston \& Beukelman, 1985). These findings indicate a possible trend in terms of differences in the frequency and quality of in-

TABLE 1: The levels of verbal expression of the subjects

\begin{tabular}{|l|c|c|}
\hline Group & $\begin{array}{c}\text { Raw score on the Expressive One } \\
\text { Word Picture Vocabulary Test } \\
\text { (Gardner, 1979) }\end{array}$ & $\begin{array}{c}\text { Average percentage: } \\
\text { Communication Assessment } \\
\text { Schedule for Severely Handicapped } \\
\text { Students (Wium and Alant, 1993) }\end{array}$ \\
\hline $\begin{array}{l}\text { Group one } \\
\text { (non-speaking) }\end{array}$ & $0-14$ & $0-5 \%$ \\
\hline $\begin{array}{l}\text { Group two } \\
\text { (highly verbal) }\end{array}$ & Above 20 & $75-100 \%$ \\
\hline $\begin{array}{l}\text { Group three } \\
\text { (miscellaneous) }\end{array}$ & $15-19$ & $10-70 \%$ \\
\hline
\end{tabular}

Due to the fact that the Expressive One Word Picture Vocabulary Test (Gardner, 1979) was standardised on normal children, the subjects (all mentally handicapped) could only be compared by using the raw scores as stanines placed them all in the same category. 
teractions between teachers and the speaking as well as non-speaking children in their classes.

This study focuses on the teacher's interaction with nonspeaking children in the class. The definition of non-speaking has elicited much controversy (Matas, Mathy-Laikko, Beukelman \& Legresley, 1985). For the purpose of this study the term refers to children with less than 15 intelligible words so as to exclude those who are beginning with functional verbal communication (Burd, Hannes, Bornhoeft \& Fisher, 1988). The purpose of this study was to describe the opportunities for interaction, offered to the non-speaking children in a classroom setting, in order to determine whether the teacher's interaction with the nonspeaking children differed in terms of quantity or quality from the teacher's interaction with the non-speaking children.

\section{METHOD:}

\section{AIM:}

The goal of this study was to describe the interaction between a primary school teacher and the non-speaking as well as spcaking children in the class, during the presentation of various lessons. The subgoals were firstly to determine the number of interactions the teacher directed at the non-speaking children in comparison with the number of interactions directed at the speaking children and secondly to determine the types of verbalizations that the teacher directed at the non-speaking children.

\section{SUBJECTS:}

The study was conducted at a school for children with impaired cognitive abilities. The school is primarily Afrikaans-speaking and has three levels, namely a beginner's phase, a junior phase and a senior phase. A class in the junior phase was selected in consultation with the principal. All the children in the class had normal vision, normal hearing and sufficient'motor abilities in order to function independently in the classroom. At least one parent of each subject was receiving a fixed income and all the children in group 1 (non-speaking) or group 2 (speaking) spoke Afrikaans as a home language.

The speech and functional communication of each child was evaluated using the Peabody Picture Vocabulary Test - Revised (Dunn \& Dunn, 1981), the Expressive One Word Picture Vocabulary Test (Gardner, 1979) as well as the Communication Assessment Schedule for Severely Handicapped Students (Wium \& Alant, 1993).

According to the children's results on the Expressive One Word Picture Vocabulary Test (Gardner, 1979) as well as the Communication Assessment Schedule for Severely Handicapped Students (Wium \& Alant, 1993) the class was divided into three groups, namely a non-speaking group, a highly verbal group and a third group which consisted of children who did not fulfil the requirements for either group one or two. Table 1 displays the levels of verbal expression of the subjects in each group and Table 2 gives a description of the children in the class.

From the criteria, specified in Table 1, for the inclusion into group one or group two it is clear that group one and two differ significantly in terms of their levels of verbal expression.

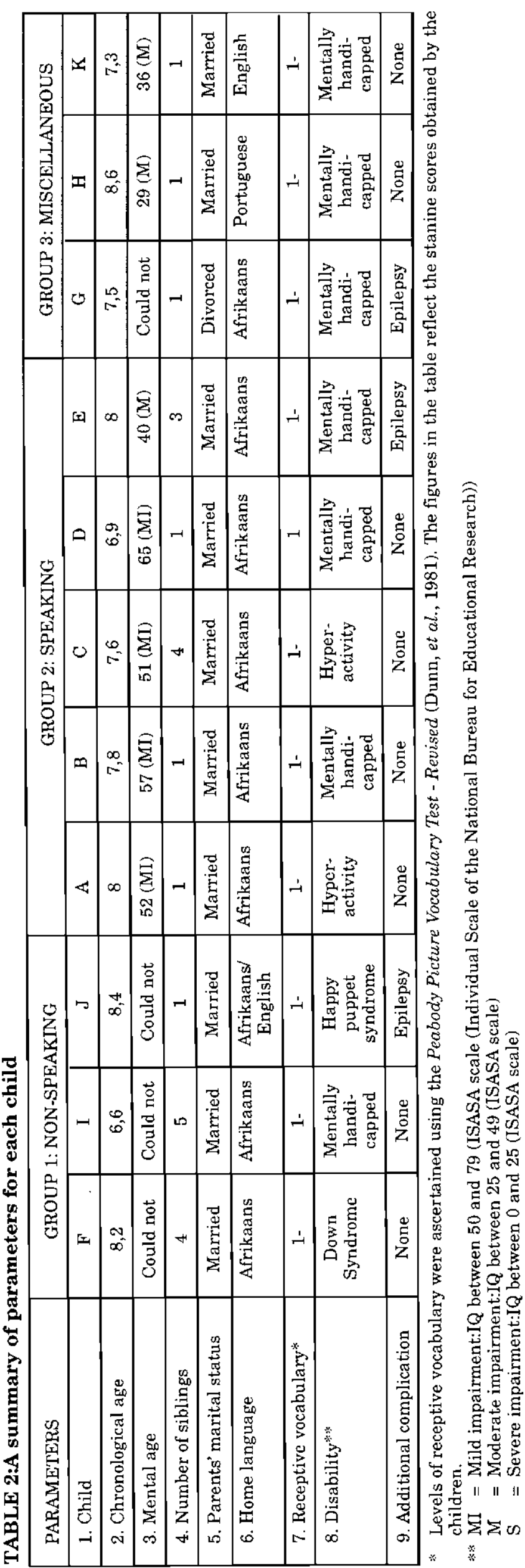




\section{PROCEDURE:}

To determine the procedure needed to evaluate classroom interaction a pilot study was conducted. The aims of the pilot study were to determine the recording equipment, as well as the recording procedures and analytical procedures to be utilised in the main study. According to the results of the pilot study the following procedures were determined for the main study.

\section{Pre-recording procedures:}

The researcher interacted with the children during teatime and playtime to allow them to familiarise themselves with her, in order to minimize the effect of her presence in the classroom. The teacher was informed that the purpose of the study was to determine the need for AAC in her classroom with the possible aim of intervention in the school. The teacher was asked to continue with her lessons as usual, while the researcher observed and audiotaped them. Two types of lessons were recorded, namely, perception training and scholastic abilities training. Perceptual training classes were concerned with the development of skills such as visual perception and auditory processing whereas scholastic abilities classes were concerned with academic skills such as maths and geography.

\section{Recording procedures:}

Audio-recordings were made using a cassette recorder and a condenser lapel microphone. Each recording was twenty minutes long. Recordings were made on Tuesdays and Wednesdays for five consecutive weeks. Ten recordings were made for each of the two types of lessons. The researcher set up the recording equipment and attached a lapel microphone to the teacher's collar. When all the children were seated in a half circle in front of the teacher, the researcher switched on the recording equipment. The researcher sat behind the children, looking towards the teacher and observed the teacher presenting the lesson. After twenty minutes (when the lesson was over), the researcher switched off the recording equipment and removed the lapel microphone from the teacher's collar. While the teacher continued with the day's work, the researcher listened to the audio recording to determine if it was clear to whom each statement had been addressed. The researcher consulted the teacher when it was uncertain. At a later stage, the audio recordings were transcribed and analysed verbatim. The materials used during recording were an Aiwa condenser lapel microphone as well as a Philips D6280 cassette recorder.

\section{Transcription procedures:}

The audio soundtrack was transcribed verbatim and checked with the teacher in order to clarify at whom each statement had been addressed. The external rater simultaneously made an independent transcription and analysis, and points of disagreement were reconsidered until $100 \%$ agreement was achieved. In order to ensure that the raw data was transcribed consistently correctly, by both transcribers, certain transcription rules were followed (Stuart, Vanderhoof \& Beukelman, 1993), namely: repetitions of words were included; vocalizations that were not actual words were represented and transcribed in a consistent form, e.g., mhmmm, uhhuh, huhuh, mmm, uh, ah, aw, whoop; numbers were typed as proper nouns; contractions were typed as such that the proper form was spelled out only when it was spoken that way, e.g., don't was typed as don't and do not was typed as do not; standard abbre. viations were included, e.g., Dr./Mrs.; during the transcription of a communication segment that was unintelligible and the entire segment was skipped even when a few intelligible words were available. A spell checker was used on all transcripts before proceeding with further analysis.

\section{Analysis of data:}

Quantitative data was established by determining at whom each interaction had been directed and calculating frequencies and proportions. The total number of interactions that the teacher directed at each of the non-speaking children, was ascertained in order to compare the amount of interaction directed at the speaking and the non-speaking children.

Qualitative data was obtained by defining twelve types of teacher verbalizations (adapted from Romski, Sevcik, Reumann \& Pate,1989) and categorising the teachers verbalizations accordingly. The twelve types of verbalizations are as follows:

1. Questioning: A sentence adapted by order of words, punctuation or intonation to elicit information. (e.g., Is it a shirt? Sharon? Tell me ...)

2. Attention directing: To guide the child's thoughts to a specific topic. (e.g., Look here.)

3. Answering: A reply to a child's verbalization and not merely negating or affirming. (e.g., Yes, it is a shirt.)

4. Requesting: Asking for an action, object or comment. (e.g., Fetch me the cow.)

5. Imitating (the child): To mimic the child's utterance with or without expansion. (e.g., Hard.)

6. Naming: To designate an object or action. (e.g., It's a shirt.)

7. Negating: To imply that what the child said or did was wrong. (e.g., No, it's not a shirt., Uh-uh.)

8. Affirming: To imply that what the child said or did was right. (e.g., You are very clever.)

9. Greeting: A salutation. (e.g., Hello friends.)

10. Self-repetition: To reproduce their own verbalizations in more or less the same form. (e.g., What is it? What is it?)

11. Informative: To state facts or opinions about a certain topic. (e.g., They run with these pants.)

12. Uncodable: The utterance does not fall into one of the above communication function categories. (e.g., Huh? Incomplete sentences).

The types of verbalizations directed at group 1 as well as the types of verbalizations directed at group 2 were ascertained, during perceptual as well as scholastic classes. In order to increase the reliability of scoring, the researcher's transcription and analysis of the recordings were checked by an external controller. Final decisions were based on $100 \%$ agreement between the raters. In order to determine the consistency of the results the change over five weeks, in the types of verbalizátions that the teacher directed at group 1, as well as group 2, was determined.

A T-test was completed to determine if there was a sig- 
nificant difference between the proportions, and finally the total proportion of time that the teacher spent in interaction with each of the non-speaking children was ascertained. In order to reveal if the results were consistent over time the change over five weeks in the proportion of time that the teacher spent in interaction with group 1 as well as group 2 was determined.

\section{RESULTS AND DISCUSSION}

The results will be discussed with reference to the aims, namely, the number of interactions directed at each child as well as the types of verbalizations used during interaction.

\section{- THE PROPORTIONS OF INTERACTION -}

Figure 1 displays the relative amount (\%) of interaction that the teacher directed at each of the subject groups.

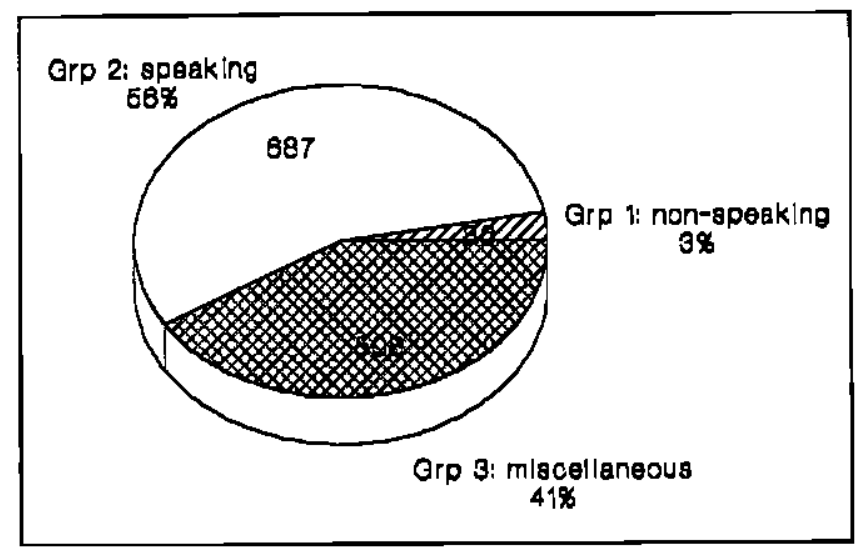

FIGURE 1: A global view of the amount of interaction directed at the three groups within the class.

The teacher directed $41 \%$ of the interactions at the whole class as well as theichildren in group three, $56 \%$ of the interactions at the speaking children and $3 \%$ of the interactions at the non-speaking children. The teacher only directed approximately $1 \%$ of her interactions towards each non-speaking child, while directing approximately $11 \%$ of her interactions towards each speaking child. This means that approximately $10 \%$ less interactions were being directed at each of the non'-speaking children, in comparison with the number of interactions directed at each of the speaking children. The above-mentioned figures are only hypothetical proportions however, as they are based on the assumption that the teacher interacted equally with each child in a specific group.

A t-test was completed to determine if the two groups (non-speaking children and speaking children) differed significantly. The variable being compared, in the two groups, was the number of interactions directed at the two groups of children by the teacher. The t-test result was 3,31 , which is larger than 2,447 , resulting in the null hypothesis (the null hypothesis supposes that there is no significant difference) being rejected. Therefore it is clear that there is a significant difference between the amount of interaction directed at the two groups. The teacher interacted significantly less with the non-speaking children, than with the speaking children.

These findings coincide with the findings of previous studies that the number of interactions uttered by the teacher is affected by the child's level of verbal output (Mirenda \& Donnellan, 1986). This is noteworthy, as it has been shown that a lack of interaction with the teacher could lead to the isolation of the child in the class, a lack of participation, and consequently to the development of passivity in the non-speaking child (Basil, 1992). As the non-speaking child is being given less opportunities to participate, he is therefore also being limited in terms of developing and practising new skills. Literature proposes that learning in the non-speaking child is reduced, due to insufficient opportunities for interaction being offered to the child (Musselwhite \& St. Louis, 1989). An increase in the amount of verbalizations, directed at the non-speaking child will, however, not necessarily guarantee an increase in learning. To ensure participation and learning the child needs to have a means by which to interact in the classroom and, for that reason, an alternative communication system should be made available to the child (Musselwhite \& St. Louis, 1989).

The teacher directed less interactions at the non-speaking group in comparison with the amount of interactions directed at the speaking group. In order to determine whether the teacher interacted equally seldom with all the children in the non-speaking group, her interaction with each of the non-speaking children was analysed individually. Figure 2 displays the relative amount $(\%)$ of interactions that the teacher directed at each of the nonspeaking children (group 1).

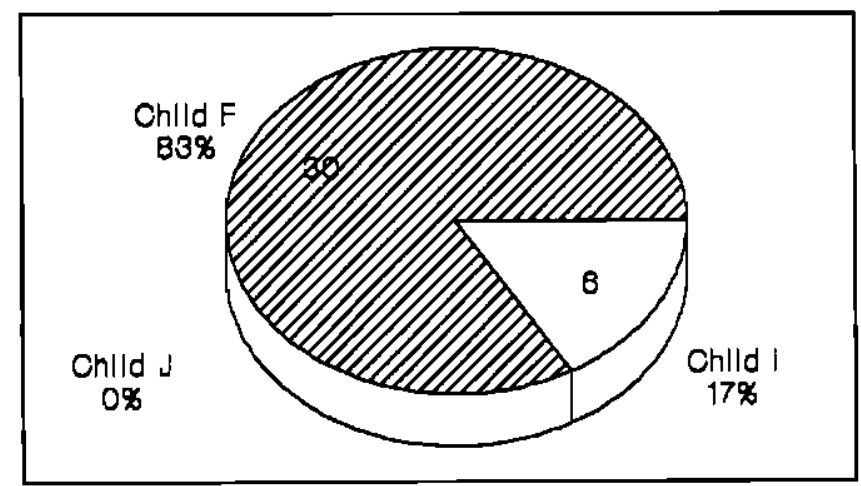

FIGURE 2: A global view of the amount of interaction directed at each of the non-speaking children.

Out of the 36 interactions directed at the three children in group $1,83 \%$ of the interactions were directed at child $\mathrm{F}, 17 \%$ of the interactions were directed at child I and $0 \%$ of the interactions were directed at child J. This means that there is not only a discrepancy between the amount of interactions that the teacher directed at each of the two groups (non-speaking children and speaking children), but that there is also a discrepancy between the number of interactions that the teacher directed at each of the non-speaking children. This opens the door to the possibility that more issues are at stake, than merely the question of verbal abilities, and these issues could influence the teacher's interaction with each of the speaking children as well.

Possible reasons, for the difference in the amount of interaction directed at each of the non-speaking children are, the child's personality (Beveridge, Ramsden \& Leudar, 1989), the teacher's expectations of the child as well as the teacher's ability to predict the child's capabilities in interaction (Light \& McNaughton, 1993), and finally, the 
child's communicative abilities (Mirenda \& Donnellan, 1986).

The presence of aggression and disruptive behaviour in a child has been shown to have a negative influence on the teacher's interaction with that specific individual (Beveridge et $\alpha l$., 1989). In this study two non-speaking children, at whom the teacher directed the least number of interactions, had behavioural problems (hitting and biting), whereas the third non-speaking child did not. However, one must consider that the teacher only interacted with all three of the non-speaking children for $3 \%$ of the total interaction time while she interacted with each of the speaking children for approximately $10 \%$ of the total time. This means that, although the child's personality may influence the teachers interaction, the child's verbal ability will have a far greater influence.

From Figure 1 it is apparent that the teacher spent only a small proportion of time in interaction with the nonspeaking children. A further analysis was done in order to determine the impact of the lesson content on the amount of interaction directed at the non-speaking as well as speaking children. Figures 3 and 4 display the relative amount (\%) of interaction that the teacher directed at each of the subject groups, during perceptual and scholastic classes respectively. This allows for a comparison of the teachers interaction with the two groups of children, during different class activities.

During perceptual classes only $2 \%$ of the interactions were directed at the non-speaking group of children, but $5 \%$ of the interactions were directed at the non-speaking group during scholastic classes. Although there is a relatively small difference, it is still significant, because the teacher interacts with the non-speaking children for such a small proportion of time. This means that the non-speak-

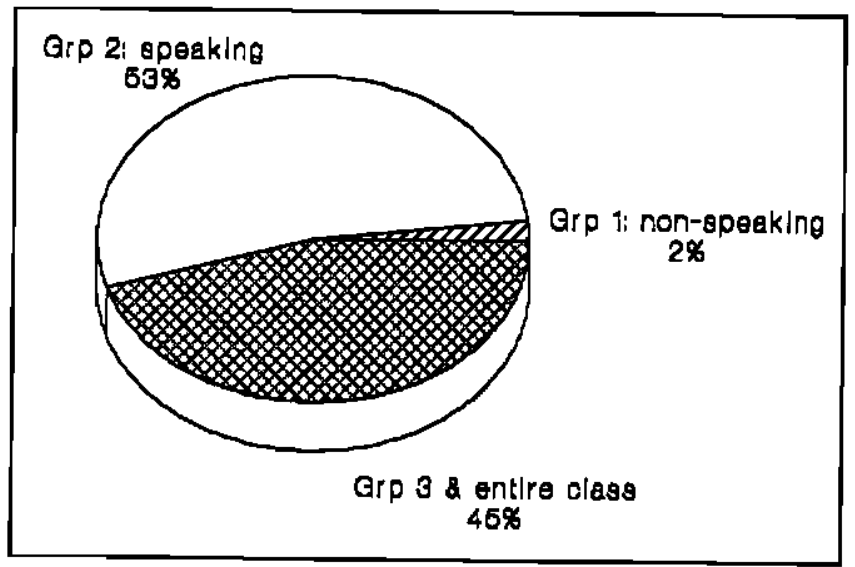

FIGURE 3: The amount of interaction directed at the speaking children and the non-speaking children during perceptual classes. ing group of children got more than twice the stimulation during scholastic classes, in comparison with perceptual classes.

In order to determine whether the results were representative of the classroom interaction a further analysis was done to determine the consistency of the results over time. Table 3 displays the amount of interaction directed at the non-speaking children, over a period of five weeks.

From the global proportions, depicted in Table 3, one can see that the values obtained for the non-speaking children do not show much variation over time, and the results obtained were a true reflection of the interaction patterns in the classroom. A trend becomes apparent, namely that the teacher consistently spent a small proportion of the total amount of time in interaction with the non-speaking children. When comparing the proportions obtained in the perceptual classes to the proportions obtained in the scholastic classes, there is consistently more interaction during the scholastic classes, with one exception. During the third week the trend was reversed, with considerably more time spent in interaction during the perceptual class, than during the scholastic class.

In order to establish whether the teacher merely spent less time in interaction with the non-speaking children, or whether there were differences in terms of the quality of interaction directed at the two groups of children, the types of verbalizations directed at the non-speaking as well as speaking children were also determined.

\section{- THE TYPES OF VERBALIZATIONS USED IN IN. TERACTION -}

In the analysis of the classroom interactions each of the teacher's utterances was categorised into one of twelve

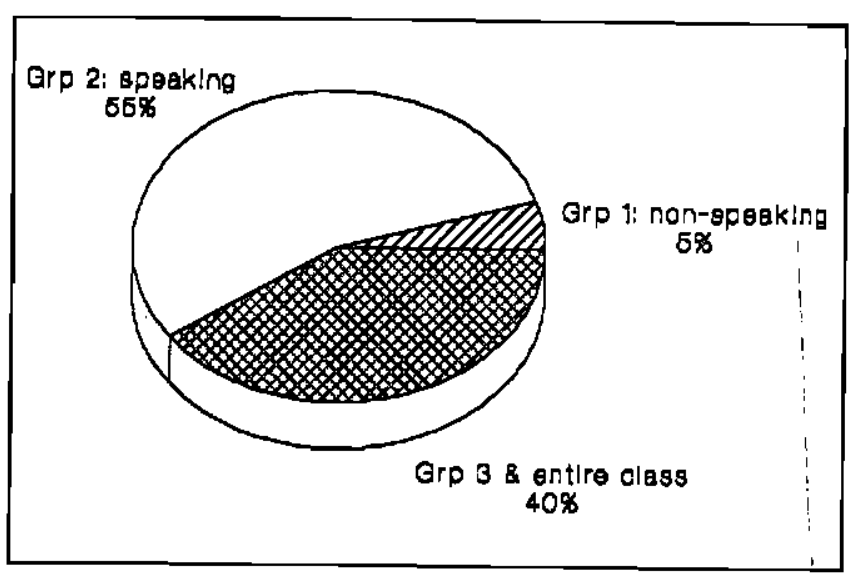

FIGURE 4: The amount of interaction directed at the speaking children and the non-speaking children during scholastic classes. TABLE 3: The amount $(\%)$ of interaction that the teacher directed at group 1 (three non-speaking children),
over a period of five weeks.

\begin{tabular}{|l|c|c|c|c|c|c|}
\hline lëssons & week 1 & week 2 & week 3 & week 4 & week 5 & average \\
\hline global view & $1,93 \%$ & $4,23 \%$ & $2,27 \%$ & $4,58 \%$ & $1,08 \%$ & 0.03 \\
\hline perceptual classes & $1,92 \%$ & $1,76 \%$ & $3,55 \%$ & $2,13 \%$ & 0 & 0.02 \\
\hline scholastic classes & $1,94 \%$ & $8,89 \%$ & 0 & $8,08 \%$ & $2,29 \%$ & 0.05 \\
\hline
\end{tabular}


types of verbalizations. Figure 5 displays how many times each of the 12 types of verbalizations occurred in the teacher's interaction with the non-speaking group of children, as well as in the teacher's interaction with the speaking group.

As displayed in figure 5, only 7 of the 12 types of verbalizations occurred in the teacher's interactions with the non-speaking group of children. Type 1 (questioning) occurred the most (11 times), followed by type 2 (attention directing) which occurred 8 times and type 4 (requesting) which occurred 7 times. Type 6 (naming), type 7 (negating), type 8 (affirming) and type 11 (informative) also occurred. Type 3 (answering the child) and type 5 (verbally imitating the child) did not occur at all. This means that the teacher's interaction with the non-speaking children was dominated by questions, attention directing and requests.

One can see that the teacher's interaction with the speaking children did not follow the same trends in terms of which types of verbalizations that occurred the most. Type 1 (questioning) still occurred the most (198 times), but type 8 (affirming) and not type 2 (attention directing) occurred second most. Type 4 (requesting) still occurred the third most. One can therefore determine a general trend in the class, namely, that questioning and requesting occur frequently, but that attention directing occurs much more frequently in the teacher's interaction with the non-speaking children. The fact that type 11 (informative) occurs much more frequently in the teacher's interaction with the speaking children than in the teacher's interaction with the non-speaking children is also of interest due to the implications for the non-speaking child's opportunity for learning in the class.

The quality of the teacher's interaction was, therefore, also influenced by the children's verbal abilities. The teacher used a limited variety of utterances when in interaction with the non-speaking children. This is of par-

\begin{tabular}{|l|l|l|l|l|}
\hline & & \\
\hline
\end{tabular}

FIGURE 5: A global view of the types of verbalizations directed at the speaking and non-speaking children. ticular relevance in the classroom situation, because the teacher's input strategies will greatly influence the child's subsequent communicative performance (Mirenda \& Donnellan, 1986). The child's verbal disability should, therefore, be considered in relationship to the interaction partner's behaviour, rather than in absolute terms (Mirenda \& Donellan, 1986). The teacher's verbalizations, directed at the non-speaking children, consisted of a large proportion of questions, attention directing and requests. This confirms the literature which states that teachers' interactions with non-speaking children are characterised by the high frequency of questions (Klein \& Harris, 1986). This type of interaction is characteristic of a directive conversational style, and may further inhibit the interaction with the non-speaking child (Mirenda \& Donellan, 1986). Consequently, the question arises of why the teacher used so many questions with the non-speaking children. Hills (1986) proposes that it is a technique used by teachers to elicit responses from children and to avoid awkward silences. It has also been hypothesised that it could be a compensatory strategy on the teachers' behalf, to compensate for the child's conversational difficulties (Mirenda \& Donellan, 1986).

The high frequency of verbalization type 4 (requesting) is not surprising, as requesting for actions or objects does not require a verbal response from the child. The fact that type 3 (answering the child) or type 5 (verbally imitating the child's verbalizations) did not occur is also to be expected, as the teacher cannot answer or imitate a child who does not speak. The frequent occurrence of affirming (type 8 verbalization) in the teacher's interaction with the speaking children could be attributed to the fact that the speaking children were more involved in the lessons, and therefore had more opportunities to give the correct response.

Figures 6 and 7 display the types of verbalizations that the teacher directed at the non-speaking children, as well as speaking children, during perceptual and scholastic classes respectively. From figure 5 it is apparent that the teachers' interaction with the two groups of children was characterised by certain trends. A further analysis was done to determine the impact of the lesson content on the types of verbalizations directed at the non-speaking children.

The same trends are seen in the two types of classes as were noted in general, for the non-speaking group, except for the following: type 6 (naming), type 8 (affirming) and type 11 (informative) did not occur in the perceptual classes and there was a relatively large number of type 11 (informative) verbalizations during scholastic classes.

A greater proportion of the teacher's interactions with the non-speaking children, occurred during scholastic classes. Perceptual skills already start to develop in sensorimotor stage one (Louw, 1990) and the skills required from the children during the classes were on a very basic level (e.g., differentiate between loud and soft). However, the scholastic classes required a higher level of functioning and the teacher therefore had to instruct the children more frequently.

In order to determine whether the results depicted in figures 5,6, and 7 were consistent and representational of all five weeks, Table 4 compares the results obtained for each of the five weeks. Any changes over time, would then become apparent.

From the results, depicted in table 4, one can see that 
the trend discussed previously (the high frequency of questioning, attention directing and requesting in the teacher's interaction with the non-speaking children) is indicated for all five weeks. However, in week 4 there is also a relatively high frequency of informative verbalizations

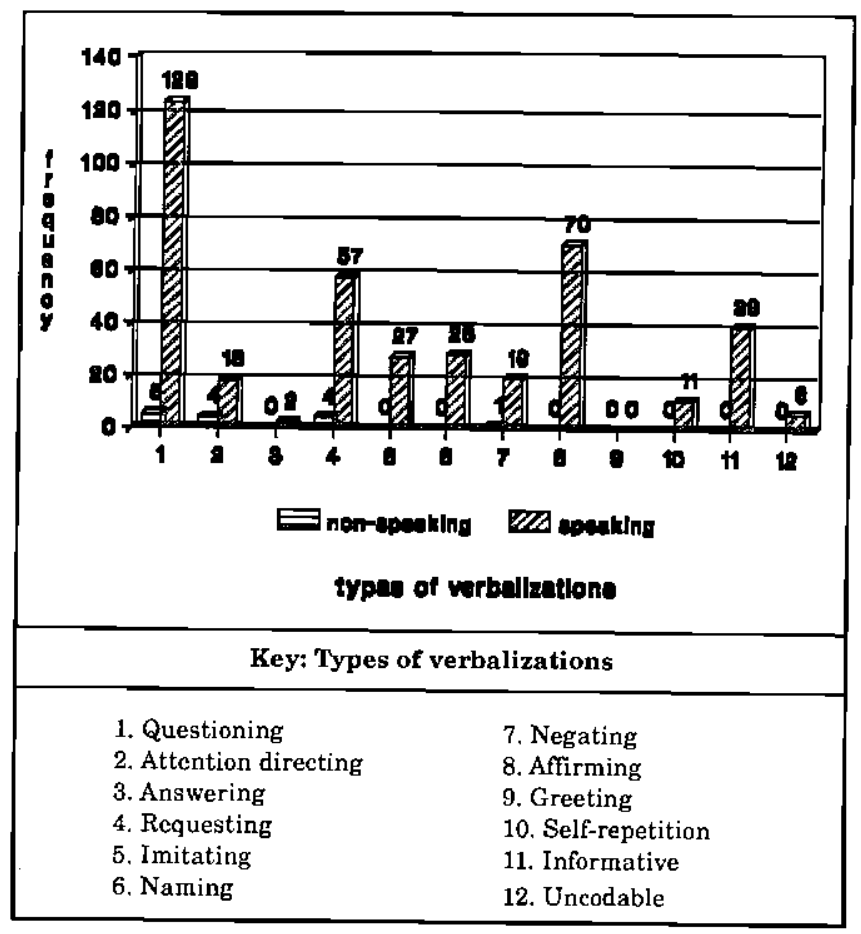

FIGURE 6: The types of verbalizations directed at the speaking and non-speaking children during perceptual classes. directed at the non-speaking children. This means that the trend is constant over time, but there is some varia. tion.

From the results discussed, it becomes clear that the teacher's interaction with the two groups differed in terms

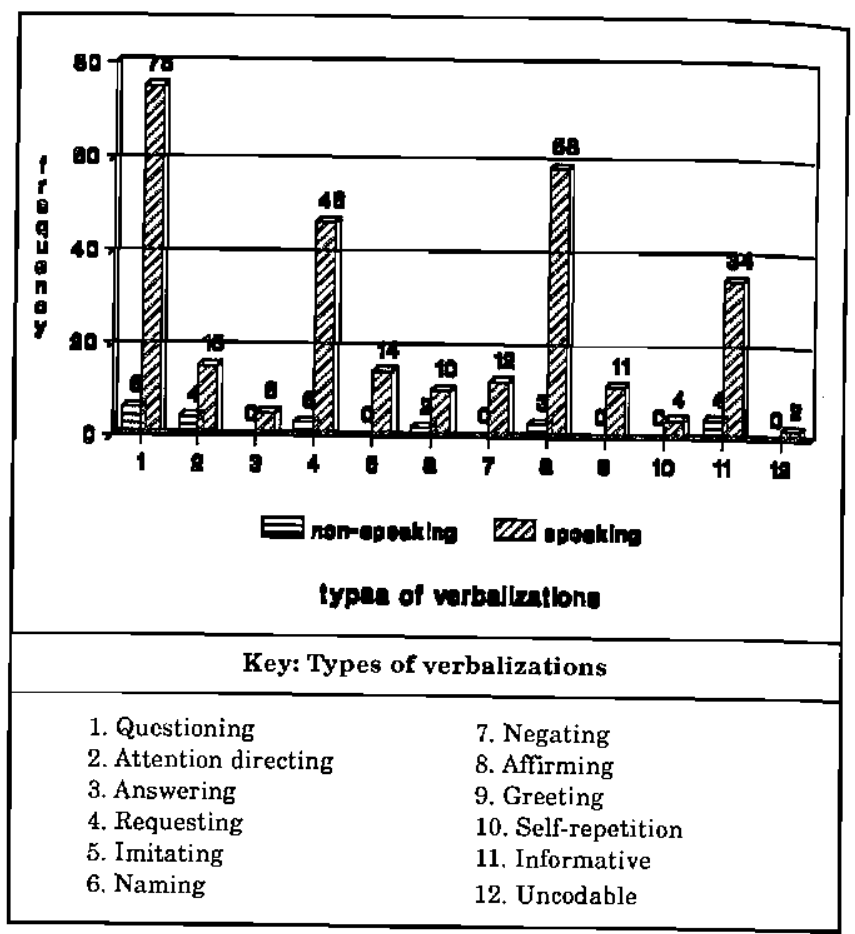

FIGURE 7: The types of verbalizations directed at the speaking an non-speaking children during scholastic classes.

TABLE 4: The number of times that each type of verbalization was directed at group-1(non-speaking children), over a period of five weeks.

\begin{tabular}{|c|c|c|c|c|c|c|}
\hline Types of Verbalizations & week 1 & week 2 & week 3 & week 4 & week 5 & total \\
\hline 1. questioning & 1 & 3 & 2 & 4 & 1 & 11 \\
\hline 2. attention directing & 3 & 2 & 1 & 2 & & $8 !$ \\
\hline 3. answering & & & & & & 0 \\
\hline 4. requesting & & 4 & 2 & 1 & & 7 \\
\hline 5. imitating & & & & & & 0 \\
\hline 6. naming & & 1 & & & 1 & 2 \\
\hline 7. negating & & & & 1 & & 1 \\
\hline 8. affirming & 1 & 1 & & & 1 & 3 \\
\hline 9. greeting & & & & & & 0 \\
\hline 10. self-repetition & & & & & & 0 \\
\hline 11. informative & 1 & & & 3 & & 4 \\
\hline 12. uncodable & 0 & & & & $\therefore$ & \\
\hline 13. total & 6 & 11 & 5 & 11 & 3 & 36 \\
\hline
\end{tabular}


of quantity and quality. One can conclude that two main trends have been identified in the teacher's interaction with the non-speaking children, namely she directed only a small amount of interaction at the non-speaking children and that she only used a limited variety of utterances when in interaction with the non-speaking children.

It has, however, become apparent that the children's verbal abilities were not the only factor which influenced the findings mentioned above, but certainly had a larger impact than the other factors.

\section{CONCLUSION}

The initial hypothesis of the study, that the teacher's interaction with the non-speaking children would differ from the interaction with the speaking children in terms of quantity and quality (Cicognani \& Zani, 1992) was proven to be correct. It has also become clear, however, that although the children's verbal ability had the greatest influence on the teacher's interaction, other factors might also have played a role. Additional factors were identified as important in determining the quantity and quality of the teacher's interaction with the non-speaking children, namely, the teacher's attitude towards the nonspeaking children, the teacher's knowledge of the importance of inclusion into interaction for the non-speaking children and the teacher's skill at including the non-speaking children in interaction (Beukelman \& Mirenda, 1992). Other important factors are the teacher's expectations of the non-speaking children and the ability to accurately predict whether a non-speaking child would be capable of completing a task (Light \& McNaughton, 1993). The nonspeaking child's personality also has a significant influence on the teacher's interactions (Beveridge et al., 1989).

A teacher's skill in involving the non-speaking child in interaction has been found to influence the child's social development and learning as well as the child's level of spontaneous participation (Kelly, 1978; Mirenda \& Donnellan, 1986). In order to change attitudes, increase knowledge and improve skills, in-service teacher training programmes could be implemented (Blackstone, 1989). Training should provide teachers with a way to monitor and modify classroom interactions, when dealing with the non-speaking child, to promote participation, development and learning (Loeding, Zangari \& Lloyd, 1990). The teachers should be involved in the process of deciding the content of the training programme (Bottorf \& DePape, 1982).

Although the teacher's interaction with the non-speaking child is an important consideration in classroom intervention, the teacher's interaction is influenced by the child's participation (Mirenda \& Donnellan, 1986). Intervention with the child is, therefore, equally as important as intervention with the teacher. Research has found that the child's role as an active participant in communication is an important factor in determining whether the interaction had been meaningful (Mirenda \& Donnellan, 1986).

Although verbal interaction was the primary mode for learning, and it was, therefore, a valid variable to consider in the study, a shortcoming of this study is that it ignored the possible impact of natural gestures and nonspeaking communication on the child. However, natural gestures as a communication system have been found to be a very limited system, in terms of the small vocabulary and the low level of abstraction (Musselwhite \& St. Louis, 1989). One could hypothesise that the use of natural ges- tures in interaction could, at best, have had a slight positive impact on the child's communication. However, further research should be done to determine the proportion and types of non-speaking interaction between the teacher and the two groups of children to determine the nature and impact thereof on the non-speaking child. Research should also investigate the teacher's interaction with nonspeaking children who have AAC systems as well as with non-speaking children who do not have AAC systems, in order to determine the impact of the AAC system on interaction.

\section{REFERENCES}

Basil, C. (1992). Social interaction and learned helplessness in severely disabled children. Augmentative and Alternative Communication, Vol. 8:3, pp 188-199.

Baumgart,D., Johnson, J. \& Helmsetter,E. (1990). Augmentative and Alternative Communication Systems for persons with moderate and severe disabilities. Paul H. Brookes Publishing Co. : Baltimore.

Beukelman, D.R. (1991). Magic and cost of communication competence. Augmentative and Alternative Communication, Vol. 7:1, pp2-10.

Beukelman, D. \& Mirenda, P. (1992). Augmentative and Alternative Communication: management of severe communication disorders in children and adults. Paul H. Brookes Publishing Co.: Baltimore.

Beukelman, D.R. \& Yorkston, K.M. (1982). Communication interaction of adult communication augmentation system use. Topics in Language Disorders, Vol. 2, pp39-53.

Beveridge, M. \& Hurrel, P. (1980). Teachers' responses to the initiations of ESN(S) children. Journal of Child Psychology and Psychiatry, Vol. 21, pp175 - 181

Beveridge, M., Ramsden, G. \& Leudar, I. (1989). Language and communication in mentally handicapped people. Chapman and Hall Ltd.: London.

Blackstone, S. (1989). Augmentative communication services in the schools. ASHA, Vol.31, pp61 - 63.

Bottorf, L. \& DePape, D. (1982). Initiating communication systems for severely speech-impaired persons. Topic in Language Disorders, Vol.2, 55 - 71.

Burd, L., Hannes, K., Bornhoeft, D. \& Fisher, W. (1988). A North Dakota prevalence study of non-speaking school-age children. Language, Speech and Hearing Services in Schools, Vol. 19:1, pp371-379.

Calculator, S. \& Luchko, C. (1983). Evaluating the effectiveness of a communication board training program. Journal of Speech and Hearing Disorders, Vol. 48, pp185-191.

Cicognani, E. \& Zani, B. (1992). Teacher-children interactions in a nursery school: an exploratory study. Language and Education, Vol. 6:1, pp1-12.

Dalton, B. \& Bedrosian, J. (1989). Communicative performance of adolescents with severe speech impairment: influence of context. Journal of Speech and Hearing Disorders, Vol. 54, pp403-418.

Dunn, L. \& Dunn, L. (1981). Peabody Picture Vocabulary Test Revised. American Guidance Service: Minnesota.

Gardner, M. (1979). Expressive One-Word Picture Vocabulary Test. Academic Therapy Publications: California.

Grayshon, M. (1977). Towards a social grammar of language Mouton Publishers: The Hague.

Harris, D. (1982). Communicative interaction processes involving nonvocal physically handicapped children. Topics in Language Disorders, Vol. 22, pp21-36.

Hills, P. (1986). Teaching and communication. Croom. Helm: Sydney.

Kelly, A. (1978). Mixed-ability grouping. Harper and Row: London.

Klein, M. \& Harris, K. (1986). Classroom communication functions of four learning-handicapped students. Language, Speech, and Hearing Services in Schools, Vol. 17, pp318-320.

Light, J. \& McNaughton, D. (1993). Literacy and Augmentative and Alternative Communication (AAC): the expectations and priorities of parents and teachers. Topics in Language Disorders, Vol. 13:2, pp33-45.

Loeding, L., Zangari, C., \& Lloyd, L. (1990). A "working party" 
approach to planning in-service training in manual signs for an entire public school staff. Augmentative and Alternative Communication, Vol. 6:1 pp38-47.

Lossing, C., Yorkston, K., \& Beukelman, D. (1985). Communication Augmentation Systems: quantification in a natural setting. Archives of Physical Medicine and Rehabilitation, Vol. 66 , pp380-383.

Louw, D. (1990). Menslike ontwikkeling. Haum-Tersiêr: Pretoria. Malamah-Thomas, A. (1988). Classroom interaction. Oxford University Press: London.

Matas, J., Mathy-Laikko, P., Beukelman, D. \& Legresley, K. (1985). Identifying the nonspeaking population: a demographic study. Augmentative and Alternative Communication, Vol. 1:1, pp 1.7-27.

Mirenda, P. \& Donnellan, A. (1986). Effects of adult interaction style on conversational behaviour in students with severe communication problems. Language, Speech and Hearing Services in Schools, Vol. 17:2, pp126-139.

Musselwhite, C. \& St. Louis, K. (1989). Communication programming for persons with severe handicaps: Vocal and augmentative strategies. College-Hill Press: Boston.

Romski, M., Sevcik, R., Reumann, R. \& Pate, J. (1989). Youngster with moderate or severe mental retardation and severe spoken language impairments 1: extant communicative patterns. Journal of Speech and Hearing Disorders, Vol. 54, pp366-372.

Stuart, S., Vandcrhoof, D. \& Beukelman, D.R. (1993). Topic and vocabulary use patterns of elderly woman. Augmentative and Alternative Communication, Vol. 9:2, pp95-107.

Wium, A. \& Alant, E. (1993). Communication assessment schedule for severely handicapped students. Unpublished study, Department of Communication Pathology, University of Pretoria. 


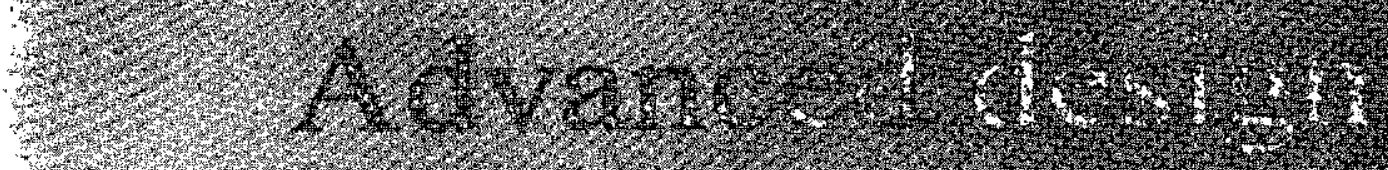

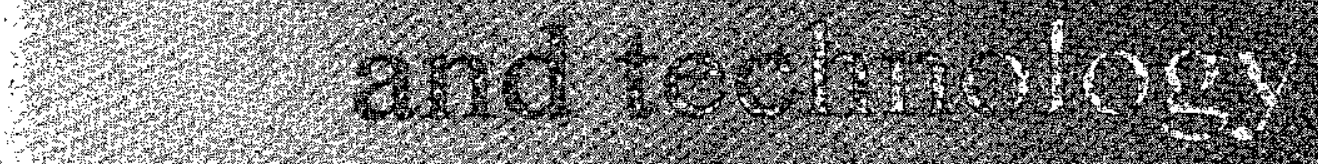
bj: (and a by

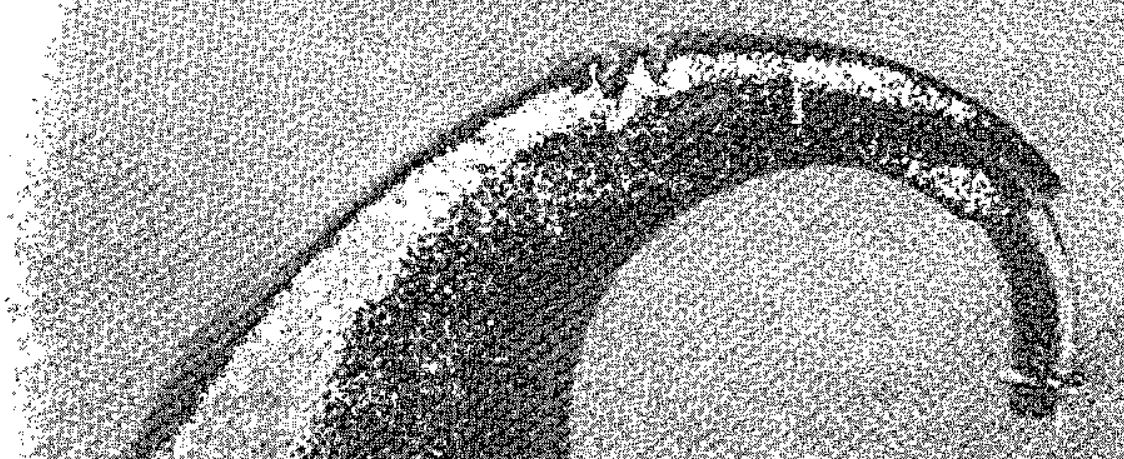

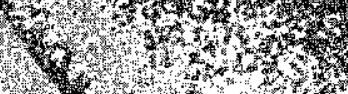

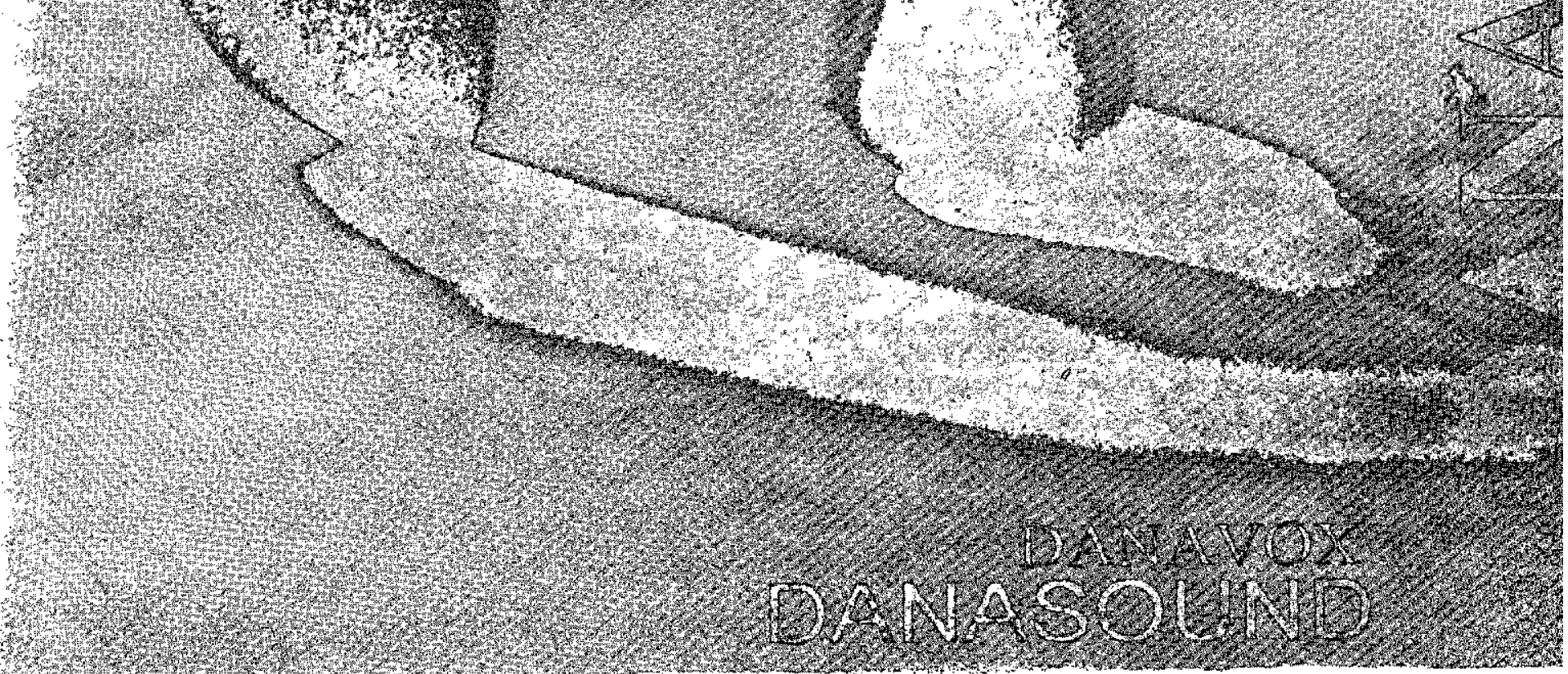


The South African Journal of Communication Disorders, Vol. 44, 1997 